\title{
DETERMINATION OF CHOLESTEROL IN ERYTHROCYTE MEMBRANE
}

\author{
Lidija Memon', Vesna Spasojević-Kalimanouska², Pavle Jović3, \\ Slavica Spasić2, Nataša Bogavac-Stanojević2 \\ ${ }^{1}$ Laboratory of Biochemistry, Bežanijska Kosa, Medical Center, Belgrade \\ 2Institutes of Medical Biochemistry, University School of Pharmacy, Belgrade \\ Institute of Clinical Biochemistry, Military Medical Academy, Belgrade
}

\begin{abstract}
Summary: Quantification of cholesterol in biological membranes is an important step toward understanding of metabolism of intracellular cholesterol, composition of cell membrane and plasma lipid profile. The aim of our study was to optimize the method for determination of cholesterol in erythrocyte membrane and then to use this method in the determination of cholesterol concentration in erythrocyte membrane in the studied group of blood samples. Cholesterol in erythrocyte membrane was determined in dry lipid extract of erythrocyte membrane by the enzymatic manual CHOD-PAP method. Cholesterol in erythrocyte membrane and plasma lipid parameters (total cholesterol, HDL-cholesterol, LDL-cholesterol and triglycerides) were determined in blood samples of 58 females, obtained by routine health control. Lipid parameters were determined by standard biochemical methods. We examined the relationship between cholesterol in erythrocyte membrane and other plasma lipid parameters as well as other atherogenic risk factors (BMI, blood pressure). Optimisation of the method for determination of cholesterol in erythrocyte membrane was based on the observation that primary cholesterol standards prepared by dissolving crystal cholesterol cannot be used due to the interference of the dissolved dry extract in organic solvents with the enzymatic reagent. Commercial standard solutions of cholesterol were used for calibration because they contain detergents for solubilisation of the dry extract in enzymatic reagent. The obtained mean value for cholesterol in erythrocyte membrane, as $\mathrm{mmol} / \mathrm{L}$ erythrocyte is $4.44 \pm 1.019$; median 4.65 ; 5 -th percentile is 2.70 , and 95-th percentile is 6.26 . In the examined female group we tested cholesterol concentration in erythrocyte membrane according to age. Two groups were formed (females below and above 50 years); using nonparametric t-test no statistically significant difference was found between these two age groups $(p>0.05)$, while plasma lipid parameters of total cholesterol, triglycerides and LDL-cholesterol were different in the examined groups $(\mathrm{p}<0.05)$. By Spearmen nonparametric correlation method we found no statistically significant correlation between cholesterol in erythrocyte membrane and other atherogenic risk factors.
\end{abstract}

Key words: membrane cholesterol, erythrocyte membrane, dyslipidaemia, atherogenic risk terol.

Abbreviations: TC total cholesterol; TG triglycerides; HDL-C HDL-cholesterol and LDL-C-LDL-holes-

\section{Introduction}

Membrane lipids play a primary role in determing both the organization and function of membranes that justifies the interest in analytical methods for lipid measurements in a membrane. In human cells, free cholesterol is normally found exclusively in membranes

\footnotetext{
Address for correspondence

Lidija Memon

Laboratory of Biochemistry,

Bežanijska kosa Medical Centre

Autoput bb

11080 Belgrade, Serbia and Montenegro

E-mail: memon@net.yu
}

where it is asymmetrically distributed between the intracellular and plasma membranes. The mechanism of cholesterol effects on membrane and cell function presumably results in part from its ability to modulate the biophysical properties of the membrane bilayer (1 3). The content of cholesterol in membranes is also important in regulation of the membrane protein transporters and cell functions $(4,5)$.

The erythrocyte membrane is a model for the plasma membranes of more complex cells. Our knowledge of plasma membranes of human cells have been greatly advanced by study of the erythrocyte membrane because it possesses several unique features: (1) it is a simple membrane, with far fewer compo- 
nents than plasma membrane of, for example, a hepatocyte; (2) the erythrocyte membrane is the only membranous component of the human erythrocyte; in contrast, the plasma membrane of a hepatocyte comprises only about $2 \%$ of the total membrane of the cell, and (3) erythrocyte membrane may be prepared simply and in large amounts.

In view of the role of excess serum cholesterol as a risk factor of atherosclerosis and its potential link to altered arterial cell and membrane function, the present study was designed to determine the possible relationship between cholesterol in membrane and lipid profile in plasma. In this purpose we determined the concentration of cholesterol in erythrocyte membrane and TC, TG, HDL-C, LDL-C in serum. For routine determination of cholesterol in erythrocyte membrane a highly sensitive and rapid method is needed with reliable imprecision and inaccuracy of the procedure so we optimised the method for determination of cholesterol in isolated erythrocyte membrane. We analysed also the distribution of cholesterol in erythrocyte membrane within different age groups and the influence of non-lipid atherogenic factors such as BMI, systolic and diastolic pressure.

\section{Material and Methods}

Blood samples were obtained from 58 apparently healthy unrelated females, aged from 22 to 64 years. Informed consent was obtained from all subjects. Serum lipid profile analyses were carried out on blood samples collected after a $12 \mathrm{~h}$ fasting period. Serum was separated by centrifugation at $3000 \mathrm{rpm}$ and lipid parameters were immediately determined. Blood samples were collected in $\mathrm{K}_{3}$ EDTA tubes for determination of cholesterol in erythrocyte membrane. Haemolysates were prepared from washed erythrocytes and stored at $70{ }^{\circ} \mathrm{C}$. The samples were thawed immediately before analysis. TC and TG were measured by standard enzymatic methods, using commercial reagent kits from Boehringer-Mannheim on multichannel analyser Hitachi 704. HDL-C was assayed by the same enzymatic method used for the TC measurement, after precipitation with phosphotungstic acid in presence of magnesium ions. The concentration of LDL-C was calculated with the Friedewald's formula (6).

\section{Enzymatic assay for cholesterol in erythrocyte membranes}

Cholesterol in erythrocyte membrane was manually determined in dry lipid extracts of the membrane by the enzymatic CHOD-PAP method using commercial kit (Randox Laboratories, Ltd. Grumlin, United Kingdom). Erythrocytes were first separated and washed from plasma. Lipids were extracted using a modification of a procedure previously described $(7,8)$.
Determination of cholesterol in erythrocyte membrane was performed in several steps. Erythrocytes were first three times washed with physiological solution and packed erythrocytes were then haemolyzed by adding distilled water in proportion (1:2); 0.5 $\mathrm{mL}$ of this haemolysate was transferred into a stoppered glass tube. With an automatic pipette $5 \mathrm{~mL}$ of isopropanol was added, drop-by-drop to a glass tube continuously mixing on vortex. The mixture was left for one hour at room temperature. Then, $3.2 \mathrm{~mL}$ of chloroform were added as described for isopropanol. After overnight storage in dark, at room temperature the tubes were virtuously mixed. The content of the tube was transferred into a glass tube graduated up to $15 \mathrm{~mL}$ and centrifuged for 10 minutes at 3000 rpm; $600 \mu \mathrm{L}$ of the supernatant was evaporated under vacuum and warming at $60^{\circ} \mathrm{C}$. Each sample was evaporated in triplicate.

Dry residue was completely dissolved in $2 \mathrm{~mL}$ of CHOD-PAP reagent (Randox) with adding $0.5 \%$ of Triton X-100. Detergent Triton X-100 must be added to the reagent solution to ensure solubilization of the lipid extracts during assay procedure. The detergent did not interfere with the assay. Incubation was carried out at room temperature for 30 minutes. Tubes were mixed several times on vortex until the dry residues were completely dissolved. Absorbances of the samples were measured at $500 \mathrm{~nm}$ on DU-8 spectrophotometer (Beckman). Blank and cholesterol standard were treated in same way as the sample after the preparation of haemolysate. Concentration of cholesterol in erythrocyte membrane was calculated using a commercial cholesterol standard $(5.17 \mathrm{mmol} / \mathrm{L})$. Values of cholesterol in erythrocyte membrane were expressed as mmol of cholesterol per $\mathrm{L}$ of erythrocytes.

\section{Statistical Methods}

All values are expressed as mean \pm SD. The examined group of females was divided in two age groups. Comparison of cholesterol in erythrocyte membrane, serum lipid values, BMI, diastolic and systolic pressure among different age groups was performed by Mann-Whitney's U-test. Significance was accepted at $p<0.05$. Cholesterol in erythrocyte membrane was also correlated with the serum lipids levels by linear regression analysis. Using statistical programs STATGRAPHIC R, VER. 4.2 and STATISTICA FOR VINDOWS, VER. 5.0 we performed statistical analyses.

\section{Results \\ Optimisation of the assay for cholesterol in erythrocyte membrane}

Quantitative determination of free cholesterol extracted from erythrocyte membrane is based on the same enzymatic method for determination of serum 
Table I Lipid and non-lipid parameters in the examined groups. Group I all women; Group II women younger than fifty years and group III women elder than fifty years.

\begin{tabular}{|c|c|c|c|c|c|}
\hline & & Group I & Group II & Group III & $p$ \\
\hline $\begin{array}{l}\text { Cholesterol in } \\
\text { erythrocyte membrane, } \\
\mathrm{mmol} / \mathrm{L} \mathrm{Er}\end{array}$ & $\begin{array}{c}\mathrm{N} \\
\overline{\mathrm{x}} \pm \mathrm{SD} \\
\mathrm{Me} \\
5,-95\end{array}$ & $\begin{array}{c}58 \\
4.44 \pm 1.019 \\
4.65 \\
2.70 \quad 6.26\end{array}$ & $\begin{array}{c}49 \\
4.45 \pm 1.029 \\
4.67 \\
2.70 \quad 6.26\end{array}$ & $\begin{array}{c}9 \\
4.38 \pm 1.014 \\
4.33 \\
2.715 .88\end{array}$ & 0.780 \\
\hline $\mathrm{TC}, \mathrm{mmol} / \mathrm{L}$ & $\begin{array}{c}\mathrm{N} \\
\overline{\mathrm{x}} \pm \mathrm{SD} \\
\mathrm{Me} \\
5, \quad 95\end{array}$ & $\begin{array}{c}58 \\
5.73 \pm 1.487 \\
5.51 \\
3.56 \quad 8.25 \\
\end{array}$ & $\begin{array}{c}49 \\
5.52 \pm 1.309 \\
5.48 \\
3.56 \quad 8.14 \\
\end{array}$ & $\begin{array}{c}9 \\
6.87 \pm 1.931 \\
6.54 \\
4.66 \quad 11.21 \\
\end{array}$ & $0.017^{*}$ \\
\hline HDL-C, mmol/L & $\begin{array}{c}\mathrm{N} \\
\overline{\mathrm{x}} \pm \mathrm{SD} \\
\mathrm{Me} \\
5, \quad 95\end{array}$ & $\begin{array}{c}58 \\
1.28 \pm 0.327 \\
1.31 \\
0.731 .89 \\
\end{array}$ & $\begin{array}{c}49 \\
1.31 \pm 0.326 \\
1.40 \\
0.80 \quad 1.89 \\
\end{array}$ & $\begin{array}{c}9 \\
1.16 \pm 0.321 \\
1.17 \\
0.681 .68 \\
\end{array}$ & 0.246 \\
\hline LDL-C, mmol/L & $\begin{array}{c}\mathrm{N} \\
\overline{\mathrm{x}} \pm \mathrm{SD} \\
\mathrm{Me} \\
5,95,\end{array}$ & $\begin{array}{c}57 \\
3.91 \pm 1.364 \\
3.64 \\
2.036 .34 \\
\end{array}$ & $\begin{array}{c}49 \\
3.72 \pm 1.156 \\
3.59 \\
2.03 \quad 5.89 \\
\end{array}$ & $\begin{array}{c}8 \\
5.05 \pm 1.993 \\
4.96 \\
2.859 .18 \\
\end{array}$ & $0.039 *$ \\
\hline $\mathrm{TG}, \mathrm{mmol} / \mathrm{L}$ & $\begin{array}{c}\mathrm{N} \\
\overline{\mathrm{x}} \pm \mathrm{SD} \\
\mathrm{Me} \\
5,95\end{array}$ & $\begin{array}{c}58 \\
1.20 \pm 0.875 \\
0.91 \\
0.38 \quad 2.86\end{array}$ & $\begin{array}{c}49 \\
1.09 \pm 0.676 \\
0.82 \\
0.38 \quad 2.36\end{array}$ & $\begin{array}{c}9 \\
1.81 \pm 1.49 \\
1.36 \\
0.955 .68\end{array}$ & $0.025 *$ \\
\hline BMI, $\mathrm{kg} / \mathrm{m}^{2}$ & $\begin{array}{c}\mathrm{N} \\
\overline{\mathrm{x}} \pm \mathrm{SD} \\
\mathrm{Me} \\
5,95\end{array}$ & $\begin{array}{c}50 \\
23.83 \pm 5.313 \\
23.19 \\
17.84 \quad 31.89 \\
\end{array}$ & $\begin{array}{c}44 \\
23.77 \pm 4.377 \\
22.77 \\
17.84 \quad 31.88 \\
\end{array}$ & $\begin{array}{c}6 \\
26.82 \pm 2.740 \\
27.27 \\
22.3130 .82 \\
\end{array}$ & \\
\hline $\begin{array}{l}\text { Systolic } \\
\text { pressure, } \mathrm{mmHg}\end{array}$ & $\begin{array}{c}\mathrm{N} \\
\overline{\mathrm{x}} \pm \mathrm{SD} \\
\mathrm{Me} \\
5,95\end{array}$ & $\begin{array}{c}33 \\
123.59 \pm 23.936 \\
120.0 \\
90 \quad 180\end{array}$ & $\begin{array}{c}26 \\
116.54 \pm 18.372 \\
120.0 \\
90 \quad 145\end{array}$ & $\begin{array}{c}7 \\
149.29 \pm 23.879 \\
140.0 \\
120 \quad 190\end{array}$ & \\
\hline $\begin{array}{l}\text { Diastolic } \\
\text { pressure, } \mathrm{mmHg}\end{array}$ & $\begin{array}{c}\mathrm{N} \\
\overline{\mathrm{x}} \pm \mathrm{SD} \\
\mathrm{Me} \\
5,95\end{array}$ & $\begin{array}{c}33 \\
76.72 \pm 11.681 \\
80.0 \\
60 \quad 90 \\
\end{array}$ & $\begin{array}{c}26 \\
74.23 \pm 11.462 \\
72.5 \\
60 \quad 90 \\
\end{array}$ & $\begin{array}{c}7 \\
86.43 \pm 4.756 \\
90.0 \\
5070\end{array}$ & \\
\hline
\end{tabular}

total cholesterol and lipoprotein fractions of cholesterol. When used for cholesterol in membrane there were some problems. Two aspects are of importance for the modified procedure: optimisations in the preanalytic treatment of the samples and standardisation of the method with an adequate water-soluble standard.

Lipid extraction from erythrocyte membrane was done by a combination of chloroform and isopropanol. Combination of chloroform as nonpolar and isopropanol as polar solvent, totally destroys hydrogen and electrostatic bonds in the lipid membrane bilayer and denatures membrane proteins.

Standardisation of the method was done with two groups of standards: primary cholesterol standards prepared in our laboratory and commercially available cholesterol standards. Primary cholesterol standards were prepared by dissolving the cholesterol, a water insoluble substance, in three organic solvents: absolute ethanol, chloroform and isopropanol. Concentration of the prepared standard was $5.17 \mathrm{mmol} / \mathrm{L}$. Cholesterol was totally dissolved in chloroform and isopropanol, but in absolute ethanol it must be warmed and continuously mixed for 23 hours. Commercial Preciset cholesterol standards (3.88 and 5.17 $\mathrm{mmol} / \mathrm{L})$, Boehringer Mannheim were used.

Experimental results suggest that different solvents for preparation of primary standards interfere with the enzymatic reaction. The influence of isopropanol is most evident at the final enzymatic reaction so the absorbance of the product is very high. Next problem was the poor solubility of dry extracts after evaporation of primary cholesterol standards in CHOD-PAP reagent even after addition of the detergent (Triton X-100). Solubility was not better even by warming at $60{ }^{\circ} \mathrm{C}$ and continuous mixing. Dry extracts prepared from commercial cholesterol standards were completely dissolved after rigorous mixing 2 to $3 \mathrm{mi}-$ nutes at room temperature. 
Table II Correlation coefficients between cholesterol in erythrocyte membrane and other lipid or non-lipid parameters

\begin{tabular}{|l|c|c|c|c|c|c|c|}
\hline & TC & HDL-C & LDL-C & TG & BMI & Systolic pressure & Diastolic pressure \\
\hline $\mathrm{N}$ & 58 & 58 & 57 & 58 & 50 & 33 & 33 \\
\hline $\begin{array}{l}\text { Cholesterol in } \\
\text { erythrocyte membrane }\end{array}$ & 0.139 & 0.020 & 0.065 & 0.186 & 0.116 & 0.246 & 0.035 \\
\hline
\end{tabular}

Imprecision of the method was evaluated in different samples of erythrocyte membranes. Small sample volume of erythrocytes is the limited factor for this assay because it is not possible to prepare numerous extracts from the same sample. From every sample we prepared one extract in which the concentration of cholesterol was determined in triplicate. Assuming the small sample volume standard deviation was determined by a pair difference method. The lowest value was subtracted from the highest value for the same extract. Calculating from 20 pairs of samples we obtained the following values: $0.253 \mathrm{mmol} / \mathrm{L} \mathrm{Er}$ for standard deviation and $5.89 \%$ for coefficient of variation.

\section{Cholesterol in erythrocyte membrane}

Concentrations of cholesterol in erythrocyte membrane, TC, TG, HDL-C, LDL-C in serum, and values for BMI, systolic and diastolic pressure in three age groups of women are summarized in Table I. To better illustrate the possible influence of old age and the effects of the decrease in female sex hormones after menopause, we divided the subjects in two groups according to age groups (females below and above 50 years). The cut-off of 50 years was chosen because this value is usually considered to be the mean age of menopause, at least in the European countries (9). Data for all three groups (Group I all subjects $N=58$; Group II age $<50$ years $N=49$; Group III age $\geq 50$ years $N=9$ ) are presented as mean value $\pm \mathrm{SD}$, median and 5-th and 95-th percentile values. Statistical differences between these two age groups for all examined parameters: cholesterol in erythrocyte membrane, TC, TG, HDL-C and LDL-C were tested by Mann-Whitney's U-test and the statistical probability is given in the Table $I$.

Mean value for cholesterol in erythrocyte membrane in the examined group of women is $4.44 \pm$ $1.019 \mathrm{mmol} / \mathrm{L} \mathrm{Er}$. Values for cholesterol in erythrocyte membrane were lower in women aged 50 years and more, but this difference is not statistically significant $(p>0.05)$. Calculated percentile values have similar variations with age. The obtained value for the 95-th percentile for group II is also lower compared with the older group (5.88 vs. $6.26 \mathrm{mmol} / \mathrm{L} \mathrm{Er}$ ).

TC and LDL-C values were evidently influenced by age. Obtained values for these parameters are statistically signicantly higher in women aged 50 years and more $(p<0.05)$. TG were also markedly higher in the older group $(\mathrm{p}<0.05)$. HDL-C as an antiatherogenic lipid parameter was lower in women aged 50 years and more, but not significantly compared with the other age group $(1.16 \pm 0.321$ vs. $1.31 \pm 0.326$ $\mathrm{mmol} / \mathrm{L}, \mathrm{p}>0.05)$.

It is well known that hyperlipoproteinaemia, obesity and hypertension constitute the main risk factors in atherogenesis and coronary heart disease. Assuming the aetiology of atherosclerosis we examined the correlation of cholesterol in erythrocyte membrane with lipid and non-lipid risk factors. We assessed the correlation between the concentration of the measured cholesterol in erythrocyte membrane with the concentrations of lipid parameters (TC, TG, HDL-C and LDL-C) and the level of BMI, systolic and diastolic pressure. In Table II results of the Spearmann-Pearson correlation method for all lipid and non-lipid parameters are presented. Negative correlations were found between cholesterol in erythrocyte membrane and other examined parameters, but these low correlation coefficients were not statistically significant. In our study BMI varied from 17.84 to $31.89 \mathrm{~kg} / \mathrm{m}^{2}$ and is probably of no importance for our results since no association between BMI and cholesterol in erythrocyte membrane has been reported.

\section{Discussion}

Epidemiological studies have indicated that elevations in plasma cholesterol constitute a principal and independent risk factor in the aetiology of atherosclerotic lesions and coronary heart disease. However, the cellular role that elevated cholesterol plays in this disease, and how it leads to lesion formation, is still intensely studied. The present study was designed to explore potential alterations of cholesterol in erythrocyte membrane associated with serum lipid profile as a predictor of atherosclerosis. As the determination of cholesterol in erythrocyte membrane is still an analytical problem, we used and optimized an enzymatic method for determination of cholesterol in serum. Several pathologies affect cholesterol in erythrocyte membrane, but its measurement has yet no relevant clinical application (10 12). The lack of simple and reliable analytical procedures does not allow a definitive agreement on the normal range of cholesterol concentrations in erythrocyte membranes.

Cholesterol in erythrocyte membrane is extracted with organic solutions and after evaporation of the sol- 
vent the dry extract is dissolved and cholesterol estimated. Cholesterol in the dry extract is also insoluble in water so addition of the detergent Triton X-100 to the extract is necessary (7). Dry extract is directly dissolved in the reagent mixture of CHOD-PAP reagent because all commercial reagents already contain detergents. We studied the effect of added Triton X100 to the reaction mixture for better dissolving of the dry extract. Our conclusion was that CHOD-PAP reagent from Randox Company already contains enough detergent.

The method must be standardized in every step: blood drawing, washing of erythrocyte and lipid extraction. The choice of anticoagulant is also important. We used $\mathrm{K}_{3}$ EDTA, but some authors used Li-heparin for collection of samples and the obtained results were $4 \%$ higher (8). Suitable erythrocyte packing is of primary importance for the reproducibility of the method. We emphasize that the indications given for the centrifugations have to be exactly followed. Under these conditions of centrifugation haematocrit always ranged $4850 \%$. The results are expressed as mmol of cholesterol per $1 \mathrm{~L}$ of packed erythrocytes but different authors express the results in different units: $\mathrm{mg} / 100$ $\mathrm{mL}$ RBC, $\mathrm{mg} / \mathrm{mL}$ RBC, nmol/109 cells, mmol/L RBC (8).

Extraction was optimised by choosing an adequate reaction mixture. Experiment results of our study confirm that chloroform-isopropanol mixture is preferred to chloroform-methanol and hexan-isopropanol mixture $(8,13)$. This combination is optimal for complete extraction of cholesterol from the erythrocyte membrane, higher lipid extraction rates and no contamination with pigments. The extraction must be done by continuous adding of extraction mixture, dropby-drop and mixing. Following strictly instructions for extraction the membrane structures are completely disintegrated, cholesterol totally extracted so there is no need for repeated extraction.

Better results are obtained with commercially available standards of cholesterol than with primary standards prepared in the laboratory. Primary standards of cholesterol prepared in different organic solvents such as ethanol, chloroform and isopropanol interfere with the solubility of the dry extract and the final enzymatic reaction. Cholesterol is an insoluble substance in water, poorly soluble in ethanol, much better dissolved in warmed ethanol and completely soluble in organic solvents (chloroform, isopropanol, ether). Evaporated extracts of primary cholesterol standards prepared by dissolving cholesterol in organic solvent were poorly dissolved in the enzymatic reagent even after addition of the detergent, Triton X100. This was not a problem with samples because erythrocyte membrane extracts have nature cell solubilisators. All these problems were negotiated using commercial available primary cholesterol standards that already contain detergents and cholesterol solu- bilisators. Dry extracts of standards are completely dissolved in enzymatic CHOD-PAP reagent. Some authors recommend the Beckman Instrument instruction for preparation of cholesterol standard (14). Cholesterol is dissolved in Triton-X-100 detergent by heating and occasional stirring. The cholesterol solution was than cooled; distilled water and Tris puffer $(\mathrm{pH}=7.4)$ were added to the proposed volume. Optimised method is accurate in determing plasma membrane cholesterol content and the precision of this method is also high. Precision is evident from relatively small standard deviations of replicates SD $=0.253 \mathrm{mmol} / \mathrm{L}$ Er and CV $=5.89 \%$.

The major advantages of the procedure for determination of the total cholesterol content in membrane lipid extracts described in the present study are the sensitivity, easy handling and the rapidity by which the assays can be performed. Furthermore, since dried lipid extracts are used, the assay procedure is insensitive to influences of different solvents for lipid extraction.

Optimised method was used for determination of cholesterol in erythrocyte membrane and the obtained mean value in our group of subjects was $4.44 \mathrm{mmol} / \mathrm{L} \mathrm{Er}$, median value $4.65 \mathrm{mmol} / \mathrm{L} \mathrm{Er}$, 5-th percentile $2.70 \mathrm{mmol} / \mathrm{L} \mathrm{Er}$ and the 95-th percentile was $6.26 \mathrm{mmol} / \mathrm{L} \mathrm{Er}$ (Table I). Our results agree with the studies of Maccia et al. (8) who examined cholesterol concentrations in erythrocyte membranes within Italic healthy population (mean value: $3.41 \mathrm{mmol} / \mathrm{L}$ Er, median: $3.41 \mathrm{mmol} / \mathrm{L} \mathrm{Er}$, 5-th percentile: 2.70 $\mathrm{mmol} / \mathrm{L} \mathrm{Er}$ and 95-th percentile $4.13 \mathrm{mmol} / \mathrm{L} \mathrm{Er}$ ). The obtained higher mean value and 95-th percentile of cholesterol in our studied group can be explained in terms of the effect of different diets between these two populations. Effect of dietary habits on cholesterol in membrane is based on the fact that most of cellular cholesterol is distributed in the plasma membrane. Enrichment of the plasma membrane with cholesterol in dietary atherosclerosis has been demonstrated (15).

Atherosclerotic risk is commonly based on measurement of lipid parameters in sera, such as TC, TG, LDL-C and HDL-C. Influences of lipid parameters and other risk factors (age, BMI and blood pressure) on cholesterol in erythrocyte membranes as a potential atherogenic marker, were analysed. As serum lipid profile changes with age, all lipid and non-lipid parameters were compared between two age groups (Table I). Older women had significantly higher values $(p<0.05)$ of TC, TG and LDL-C, which is in agreement with other epidemiological studies. Cholesterol in erythrocyte membrane and HDL-C were not affected by age.

To explore whether cholesterol levels in erythrocyte membrane were higher in presence of higher serum TC and LDL-C concentrations, we correlated the cholesterol concentrations in erythrocyte membrane with the corresponding lipid profile, hypertension and 
BMI, risk factors for initiation and progression of atherosclerosis (Table II). There was no correlation among the examined parameters, although there is literature evidence for direct correlation of cholesterol with age, gender, BMI, systolic and diastolic pressure as well as concentrations of TG, HDL-C and serum phospholipids (16). Highest influence was observed for age, gender and concentrations of TG in serum, while arteric hypertension lowers the cholesterol in erythrocyte membrane (17).

Although we obtained no correlation between cholesterol in membrane erythrocyte and TC and LDL-C, there is evidence that hypercholesterolemia influences deposition of cholesterol in the extracellular part of the erythrocyte membrane and sometimes even changes the shape of normal erythrocytes in acantocytes. Accumulation of cholesterol in the membrane causes the rigidity of the membrane in acantocytes. Literature data suggest that atherosclerosis alters the composition, structure and function of plasma membranes (18). Patients with atherosclerotic lesions have modified lipid structure in membranes, altered ratio of cholesterol/phospholipid and modified fluidity of the membrane $(19,20)$. Diagnosis of atherosclerosis is based on early structural modifications of the cells, so determination of cholesterol in erythrocyte membrane or the cholesterol/phospholipid ratio can be an important diagnostic parameter of the physicochemical alteration within the cell in the reversely phase.

We have described a sensitive, simple and accurate method for determining the cholesterol content in biological membrane. Our data contribute to the standardisation of the method in every step, determining the reference values and establishing the relation between cholesterol in membrane with some pathological states, especially the influence of cholesterol in membrane on determination of atherogenic risk and further development of atherosclerosis.

Acknowledgement: This study was conducted as a part of the project No.1223, entitled: »Investigation of genetically polymorphic proteins and other biomolecules as risk factors for development of atherosclerosis and other diseases «, financially supported by the Ministry of Sciences, Technology and Development, Republic of Serbia.

\title{
ODREĐIVANJE HOLESTEROLA U MEMBRANI ERITROCITA
}

\author{
Lidija Memon'1, Vesna Spasojević-Kalimanouska², Pavle Jović3, \\ Slavica Spasić2, Nataša Bogavac-Stanojevićc \\ ${ }^{1}$ Biohemijska laboratorija, KBC »Bežanijska kosa«, Beograd \\ 2Institut za medicinsku biohemiju, Farmaceutski fakultet, Beograd \\ 3 Institut za kliničku biohemiju VMA, Beograd
}

\begin{abstract}
Kratak sadržaj: Određivanje membranskog holesterola je važan stepen u utvrđivanju povezanosti intracelularnog metabolizma holesterola, sastava ćelijske membrane i plazmatskog lipidnog profila. Prvi cilj ovog rada je bio optimizacija metode za određivanje membranskog holesterola što je podrazumevalo izbor standarda i primenu enzimskog testa. Holesterol u membrani eritrocita određivan je ručno u suvom lipidnom ekstraktu membrane, enzimskom CHOD-PAP metodom firme Randox. Optimizirana metoda je primenjena za određivanje koncentracija holesterola u membrani eritrocita kod 58 žena kojima je krv uzeta na rutinskom sistematskom pregledu. U ispitivanim uzorcima određen je i serumski lipidni profil standardnim biohemijskim metodama. Ispitivane žene su podeljene u dve starosne grupe: na mlađe od 50 godina i na starije od 50 godina. Ispitan je i stepen povezanosti između membranskog holesterola sa jedne strane i plazmatskih lipida i drugih faktora rizika za aterosklerozu (starosti, BMI, sistolni i dijastolni pritisak) sa druge strane. Optimizacijom metode za određivanje membranskog holesterola došlo se do zaključka da se ne mogu koristiti primarni standardni rastvori holesterola dobijeni rastvaranjem kristalnog holesterola u organskom rastvaraču zbog slabe rastvorljivosti suvog ekstrakta u enzimskom reagensu i uticaja pojedinih rastvarača na bojenu reakciju. Za kalibraciju treba koristiti komercijalne standardne rastvore holesterola jer sadrže deterdžente koji omogućavaju rastvorljivost suvog ekstrakta. U ispitivanoj populaciji dobijena srednja vrednosti za holesterol u membrani eritrocita (izražene kao mmol/L eritrocita) iznosi 4,44 \pm 1,019, mediana 4,65, 5-ti percentil iznosi 2,70, a 95-ti percentil je 6,26. Poređenjem ispitivanih parametara između dve starosne grupe za holesterol u eritrocitnoj membrani nije bilo značajne razlike $(p>0,05)$ dok je za ukupan holesterol, LDL-holesterol i trigliceride ova razlika bila statistički značajna $(p<0,05)$. Primenom Spearman-ove neparametarske korelacije nije nađena statistički značajna korelacija između membranskog holesterola i drugih faktora rizika za aterosklerozu.
\end{abstract}

Ključne reči: holesterol u membrani, eritrocitna membrana, dislipidemija, aterogeni rizik.

Skraćenice: uH-ukupan holesterol; TG-trigliceridi; HDL-H HDL-holesterol; LDL-H - LDL-holesterol. 


\section{References}

1. Schroeder F, Frolov A. Recent advances in membrane cholesterol domain dynamics and intracellular cholesterol trafficking. Proc Soc Exp Biol Med 1996; 213 : 15077.

2. Malewitz B, Kumar VV. Lipids in gap junction assembly and function. Lipids 1990; 25: 41927.

3. Schroeder F, Woodford JK. Cholesterol domains in biological membranes. Mol Membr Biol 1995; 12: 1139.

4. Engelmann B, Duhm J. Effect of cholesterol and dipalmitoyl phosphatidylcholine enrichment on the kinetics of Na-Li exchange of human erythrocytes. J Membr Biol 1991; 122: 2318.

5. Chen Q, Amaral J. Excess membrane cholesterol alters human gallbladder muscle contractility and membrane fluidity. Gastroenterology 1999; 116: 67885.

6. Fridewald WT, Levy RI, Frederickson DS. Estimation of concentration of low-density lipoprotein cholesterol in plasma, without use of the preparative ultracentrifuge. Clin Chem 1972; 18: 499502.

7. Ott P, Binggeli Y, Brodbeck U. A rapid and sensitive assay for determination of cholesterol in membrane lipid extracts. Biochim Biophys Acta 1982; 685: 2113.

8. Macchia T, Mancinelli R, Barbini DA. Determination of membrane cholesterol in normal and pathological red blood cells. Clin Chim Acta 1991; 199: 5968.

9. Prior JC. Perimenopause: the complex endocrinology of the menopausal transition. Endocrine Rev 1998; 19: 397428.

10. Michalak J, Kadziolka A. Compensatory mechanisms in erythrocyte lipids in patients with atherosclerosis. Lipids 1988; 23: 47880.

11. Bryszewska M, Watala C, Torzeska W. Changes and composition of erytrocyte membranes and in composi- tion of plasma lipids in type I diabetes. $\mathrm{Br} \mathrm{J}$ Haematol 1986; 62: 1116.

12. Mazzanti L, Staffolani R. Modifications induced by gestational diabetes mellitus on cellular membrane properties. Scan J Clin Lab Invest 1991; 51: 40510.

13. Rodriguez-Vico F, Martinez-Cayuela M. A procedure for the simultaneous determination of lipid and protein in biomembranes and other biological samples. Lipids 1991; 26: 7780 .

14. Crockett EL, Hazel JR. Sensitive assay for cholesterol in biological membranes reveals membrane-specific differences in kinetics of cholesterol oxidase. J Exp Zool 1995; 271: 1905.

15. Chen M, Mason RP, Tulenko TN. Atherosclerosis alters the compositon, structure and function of arterial smooth muscle cell plasma membranes. BBA 1995; 1272: 10112.

16. Koblik T. Cholesterol and phospholipid levels in erythrocyte membrane of patients with blood lipid disorders and hypertension. Przegl Lek 1990; 47: 7505.

17. Anceschi MM, Coata G. Eryhtrocyte membrane composition in pregnancy-induced hypertension: evidence for an altered lipid profile. Br J Obstet Gynaecol 1992; 99: 5037.

18. Broadley C, Dawidowitz E. Modulation of membrane cholesterol levels: effects on endothelial cell function. Exp Cell Res 1991; 193: 14450.

19. Kruth HS. The fate of lipoprotein cholesterol entering the arterial wall. Curr Opin Lipid 1997; 8: 24652.

20. Tulenko TN, Chen M, Mason PE, Mason RP. Physical effects of cholesterol on arterial smooth muscle membranes: evidence of immiscible cholesterol domains and alterations in bilayer width during atherogenesis. J Lipid Research 1998; 39: 94756. 